\title{
WIZJA CHIŃSKIEJ REPUBLIKI LUDOWEJ W UTWORACH TADEUSZA RÓŻEWICZA SEN KWIATU, SERCE SMOKA, DWA SKOKI I JUŻ PEKIN, PRZELOT I W DRODZE
}

Różewicz napisał kiedyś o pracy twórczej: „,poeta nie porusza się ruchem postępowym, lecz po okręgu: wokół swojego centrum, jeśli takie centrum istnieje"'. Przez lata rozwijał się, zmieniał również miejsce zamieszkania. Podróżował, co często stanowiło temat jego utworów. W latach 50, na zaproszenie chińskiego Stowarzyszenia Literatów, udał się do Chin kontynentalnych. Literatura była dla niego narzędziem służącym oswajaniu kwestii, których pełne zrozumienie było niemożliwe. Myślę, że śmiało można do nich zaliczyć egzotykę Azji.

Nadzwyczajny erudyta, krytykował twórczość niektórych artystów, której treść ginęła w tumanach egzaltacji. Nie lubił banałów i płycizny współczesnej kultury. Zaowocowało to charakterystycznymi frazami tworzonych przez Różewicza wierszy. Oszczędnie i precyzyjnie dobierał słowa, eksponował pauzy i przemilczenia. Jego styl, konstrukcja języka i forma utworów bywały niezrozumiałe dla jemu współczesnych, uznawane za zbyt awangardowe. Poeta miał też bogatą wiedzę z historii sztuki². Malarskość, a może malowniczość Różewiczowskiej wizji świata widać także w opisach chińskiego krajobrazu. Wyraźnie zwracał uwagę na formy, wzory i ich ślady w języku.

W niniejszym artykule chciałabym skupić się na prozatorskiej twórczości Różewicza, a dokładnie na jego literackich wspomnieniach z podróży do Chin. Należą do nich utwory Sen kwiatu, serce smoka, wydane w tomie prozy Różewicza w 2004 r., a także Dwa skoki i już Pekin, Przelot oraz W drodz̧e z tomu Margines, ale..., wydanego w roku 2010. Chciałabym również opisać te utwory przez pryzmat swojego doświadczenia życia w Chinach i studiów sinologicznych.

Różewicz odbył podróż do stosunkowo niedawno powstałej Chińskiej Republiki Ludowej w październiku 1958 r. Opisał ją w swoich notatkach, fragmentach dziennika i „kartkach z podróży”. Nie zostały one nigdy wydane jako całość. Uważam jednak, że warto w ten sposób je potraktować i przyjrzeć się obrazowi Chin, jaki wyłania się z twórczości tego poety, prozaika i dramaturga bogatego w doświadczenia

1 W. Britaniszski, Poezja Różenicza [w:] Rzeczpospolita poetóm. Sžkice i eseje, tłum. J. Głażewski, Warszawa 2010, s. 181.

2 M. Porębski, Wstęp do metakrytyki [w:] Pờegnanie z. krytyka, Kraków 1966, s. 230. 
życiowe i surowo oceniającego formy, w jakich zamknięta jest rzeczywistość. Można także od lektury tych tekstów zacząć analizę późniejszej twórczości Różewicza i ewentualnych wpływów, jakie na nią wywarły jego azjatyckie doświadczenia.

W utworze Prz̨elot kilkustronicowy opis podróży rozpoczyna się Gombrowiczowskim wręcz podaniem szczegółów - od numeru samolotu aż po datę i godzinę. Służy to porównaniu luksusowego TU z rozklekotanym Ił-em, którym leciał do Moskwy. Narrator twierdzi, że opisuje maszynę, patrząc na nią okiem pasażera, nie konstruktora. Stewardesy nazywa „paniami domu”, ich instrukcje przygotowujące do startu - „przedstawieniem”. Jest i kurtyna. Widać w tym porównaniu przywiązanie Różewicza do teatru, prowadzące do postrzegania świata jako poruszającej się sceny. Uwage zwracają zmiany rejestru. Autor opisuje widoczne w dole światła Moskwy jako wyspy na morzu nocy, by w następnym zdaniu przywołać kształt biodra stewardesy pochylonej nad współpasażerem. Dzień łączy się ze świtem, Warszawa z Pekinem, tysiące kilometrów zlewają się w jedno. „Wyobraźnia nie obejmuje wielu rzeczy, które dzieją się tu, w tej chwili”’3. Autor, jako pasażer, jest nią rozczarowany, mówi, że wytoczył jej proces, ponieważ okazała się czymś kompromitującym i prymitywnym. Ciekawe sa porównania. Gobi widziana z góry przypomina wygarbowaną skórę lub wypaloną czerwoną cegłę. Linia kolejowa kreskę idąca przez czerwoną pustkę, a pociąg - zabawkę. Jeziora są bielmami, lasy - ciemnymi smugami.

Różewicz zwraca uwagę na konstrukcję psychiczną człowieka, który na wysokości 10 tys. metrów jest w stanie czyścić zęby lub narzekać, że nóżka kury, podana na obiad, jest zbyt twarda. Przygląda się też zachowaniu przedmiotów, nieodbiegającemu od tego, które znamy z codziennego życia: „Szklanka stoi sobie tak jak u mnie w pokoju na stole". Dzieli się spostrzeżeniami z towarzyszem literatem, co wywołuje w obu uczucie pobłażliwości dla nich samych jako bezużytecznych w procesie budowania samolotu. W końcu wizja maszyny zbudowanej przez człowieka bierze górę nad filozoficzną fascynacją wysokością. Staruszek chrapie, lot dobiega końca, a sprzątaczki wchodza, by pozamiatać brzozowymi miotłami.

Inną kulturę zwiastuje już łapka na muchy, która, według słów poety, „świadczy o przynależności samolotu lepiej, niż napisy na skrzydłach"4. Na torebce współpasażera zanotowane jest, że „czteroletni chłopiec zabił cztery tysiące much. Siedemdziesięcioletnia staruszka udaje brzęczenie komara, zwabia w ten sposób do siebie komary, które zabija"5. Ta wzmianka przenosi nas do zawartego w utworze Sen kwiatu, serce smoka opisu wizyty Różewicza w pekińskim Muzeum Zakazanego Miasta, gdzie w jednym z pawilonów znajduje się ekspozycja „czterech szkodników”. Już na zewnętrznej ścianie budynku umieszczono ozdobny meander, złożony z se-

3 T. Różewicz, Przelot [w:] Margines, ale..., Wrocław 2010, s. 16.

4 Ibidem.

5 Ibidem, s. 17. 
tek tysięcy wróblich skrzydełek ${ }^{6}$, wewnątrz - pagodę z wróblich główek. Uznane za szkodniki wróble wybito w kampanii walki z czterema szkodnikami (muchami, wróblami, szczurami i komarami), robiąc hałas i przeganiając je z miejsca na miejsce, by nie mogły spoczać, co wykańczało serca ptaków ${ }^{7}$. Na wystawie znajdują się też, między innymi, zagroda wiejska ze szczurzych ogonków, osiołek naturalnej wielkości ze szczurzych skór, setki różnych pułapek na myszy i szczury... Rozmowa autora z kustoszem wystawy nasuwa refleksje na temat systemu władzy w tym kraju. Zgodnie z jego logiką każde ziarenko ma swoją wartość, więc należało zniszczyć kradnące je ptaki. A owady, dla których wróble były dotąd naturalnymi wrogami? Je również naród niszczył samodzielnie. W ten sposób lud miał poczucie kontroli nad naturą, a rządzący - jego poparcie i zaufanie.

Inaczej wyglądało niszczenie ludzkich „szkodników” ideologicznych. Przedwojenny Szanghaj, nazywany nawet „dziwką Azji” " zamieszkiwali marynarze, prostytutki, handlarze opium, żebracy, przemytnicy i przestępcy. Autor i towarzysz jego podróży coś wiedzą na ten temat, ale nie mogą dowiedzieć się więcej - tłumacz przysłuchujący się rozmowie kwituje ich rozważania krótkim „Prostitutka niet, niet”. Domy publiczne zamknięto, sutenerów wystrzelano, prostytutki wróciły do społeczeństwa, w którym wytapiały stal i zakładały rodziny. Różewicz przytacza historię przyjezdnego marynarza, który „chciał iść na dziewczynki”" W tym celu zaczepił przechodnia, który domyślił się, o co chodzi i zabrał go do budynku władz. Tam wytłumaczono mu, że te sprawy należą już do przeszłości, a jemu samemu pozostało już tylko samotnie się upić.

Poeta porównuje europejski i chiński Szanghaj. Pierwszy przypomina miasto w Europie, napisy francuskie zlewają się na ulicach z angielskimi. Drugi jest złożony z chat, bud i domków z drewna, dykty, papy i trzciny, które stoją jedne przy drugich. Nie ma tam łąk, kwiatów, motyli i drzew. Ludzie umierali tu kiedyś w nędzy, dzieci sprzedawano, królowali przestępcy i szanghajskie gangi.

Dziś dzieci biegają grupkami, zafascynowane wielkimi nosami cudzoziemców. Polscy literaci zostaja przyjęci w biurze dzielnicowej rady narodowej, gdzie na stole stoją termosy z wrzątkiem. Te same termosy pojawiają się w relacji z Pekinu, kiedy poeta wymienia czynniki odróżniające chiński hotel od europejskiego. „W oknie rozpięta delikatna gęsta siatka. No tak. Możemy okno otworzyć, nie wleci przez oczka tej siatki ani mucha, ani komar. Na stoliku stoi karafka z woda, dwie szklanki odwrócone dnem do góry. A obok stoi duży, zielony termos. Termos jest naprawdę duży: jakieś sześć szklanek wody. To do picia"10.

Różewicz próbuje przekazać czytelnikom swoje wrażenia na temat języka chińskiego. Są one raczej trafne, chociaż nazwanie znaków chińskich „literami” budzi

6 T. Różewicz, Sen kwiatu, serce smoka [w:] Proza, t. 2, Wrocław 2004, s. 265.

D. Guo, Wushi nian liuxing ciyu (1949-1999), Jinan 1999, pkt 69.

8 S. Dong, Shanghai: The Rise and Fall of a Decadent City, New York 2000.

9 T. Różewicz, Sen kwiatu..., s. 263.

10 T. Różewicz, Dwa skoki i już Pekin (Kartki zpodróży) [w:] Margines, ale... 
mój sprzeciw, wszak każdy taki ideogram to całe słowo ${ }^{11}$. Na wystawie kwiatów w Chengdu ${ }^{12}$ poeta odnosi się jednak z szacunkiem do kultury, która stworzyła pojęcia „starsze od naszej tysiącletniej ojczyzny”. Dostrzega w nazwach kwiatów poezje, każda $z$ nich jest dla niego „małym, niezwykle celnym i czystym utworem poetyckim"13. Świadczy to o tym, że autor w trakcie pobytu w Chinach wiele się dowiedział o tamtejszej kulturze i języku. Przytacza nazwy, takie jak „sen kwiatów”, „łapa tygrysa”, „kwiat, co ośmielił swa pięknością porównać się z dziewczyną”. Sam dodaje swoje pomysły - „serce smoka”, „sen śniegu”"14. Jego refleksje dotyczą też języka poezji i zagadnienia jej przekładu - sam nie zna chińskiego, zdany jest więc na tłumaczy. Cytuje wiersz $\mathrm{Du} \mathrm{Fu}^{15}$, jednego z najsłynniejszych poetów czasów dynastii Tang (618-907 r.). Przyrównuje jego niemiecki przekład do odbicia w zamglonym lustrze. $Z$ wdziękiem stwierdza, że z oryginału zrozumiał niewiele więcej niż ze śpiewu ptaków w ogrodzie. Opisuje żmudny proces tłumaczenia dawnej poezji z klasycznego języka chińskiego na współczesny mandaryński i na języki europejskie. Nie bez powodu przypuszcza, że z ostatecznego produktu „wyciekła tajemnica poety" ${ }^{\prime 16}$.

Krajobrazy podziwiane przez Różewicza z okien pociąu są bardzo różne czterdzieści sześć godzin podróży wystarczy, by napatrzeć się na wiele wariantów chińskiego świata. Z okien widzi pracujących w pocie czoła ludzi (powtarza się fraza „naród wytapia żelazo, stal”), ale i wiejski krajobraz pełen roślin, glinianą ziemię zmyta strugami deszczu, ogrody. Ten ogromny kraj jest niejednolity i poeta potrafi pięknie to podsumować:

Ziemia jest szara. Szary pył. Później poznałem różnobarwne oblicze ziemi tego wielkiego kraju. Ziemię czerwona, ziemię ognistą, ziemię płową, ziemię czarną i tłustą, ziemię pokrytą zielenią ryżu, ziemię skalistą, ziemię okrytą kwiatami i motylami. Ziemię przypominającą wypalony potrzaskany dzban z gliny i ziemię rajskich ogrodów. A przecież to była tylko część oblicza chińskiego kraju.

(Dwa skoki i jǜ Pekin, s. 11)

Opisuje Chińczyków uprawiających gimnastykę jako ważny aspekt kultury fizycznej narodu, ale też ciekawy obrazek obyczajowy, pogrą̇zony we mgle. Nie umykają jego uwadze tysiące grobów, które w obliczu kurczącego się terenu są przenoszone na obrzeża miast. Jest to ciężkim ciosem dla ludzi wychowanych w tradycji kultu przodków. Widzi też piece do wypalania żelaza: „Wśród tysięcy grobów paliło się tysiąc płomieni pod milczącym niebem”17. W utworach Różewicza zawarte są za-

11 T. Różewicz, Prželot..., s. 17.

12 U Różewicza „Chengtu”, ja jednak używam współczesnej transkrypcji pinyin.

13 T. Różewicz, Sen kwiatu..., s. 257.

14 Ibidem.

15 U Różewicza: „Tu Fu”.

16 T. Różewicz, Sen kwiatu..., s. 260.

17 Ibidem, s. 261. 
równo krótkie, barwne i celne aluzje do polityki władz, jak i do sytuacji społeczno-kulturowej Chin. Opisuje na przykład stos sandałów wyplecionych ze słomy, takich samych jak te, w których maszerowali żołnierze - bohaterowie „Długiego Marszu”, i dodaje, że „Wielki marsz trwa tu ciagle”.

Wizja Mao o nieprzerwanej rewolucji spełnia się na oczach poety. „Naród ruszył z miejsca. Mogę tylko patrzeć". Zdaje sobie sprawę z tego, jak trudno będzie opisać to, co widzi: „wydaje mi się, że mam wymalować pejzaż. Krajobraz z człowiekiem w środku - na ziarnku ryżu. Ale nie mam do tego ani odpowiedniego piórka, ani barw, ani umiejętności i... mam bardzo słaby wzrok". Zachowuje pewien dystans, podchodzi do opisywanej rzeczywistości z życzliwym szacunkiem, zdając sobie sprawę z tego, jak wielu spraw nie rozumie. Stwierdzając coś z całą pewnością, ociera się o błędy, jak w obserwacji: ,żaden Chińczyk z tych 600 milionów nie ma niebieskich oczu"18 - znane są wszak przypadki potomków europejskich uciekinierów z Syberii, którzy rodzą się jako Chińczycy z niebieskimi oczami. Docenia gościnę gospodarzy, stosuje się do ich kuriozalnych zaleceń („Nie wolno wam przez tydzień pić alkoholu i kąpać się; możecie przy kąpieli zatrzeć to miejsce, gdzie był zastrzyk, i może się zakazić skóra"). Ten świat jest inny i poeta nie ocenia go, czasami nawet nie rozumie, co widać w lakonicznym dialogu ze współpasażerem:

- Staram się zrozumieć.

- Ja też.

- Ale tylko na początku podróży myślałem, że coś wiem...

- Myślę, że to się po jakimś czasie podsumuje.

- Tak myślisz?

- Co chcesz, to inny świat.

- Inny.

(Sen kwiatu, s. 268)

Niektóre zjawiska ocenia Różewicz pozytywnie. W utworze $W$ drodæe pisze, że bardzo mu się podoba chińska młodzież, uśmiechnięte twarze, kwiaty, potrawy, pałace, opery. Zdaje sobie jednak sprawę z tego, że inne zjawiska zostały przed nim zakryte i że nie było mu dane widzieć łez, cierpienia, ludzi poniżonych i rozpaczajacych. Otwarcie przyznaje, że nie wie, czy to, co napisał o Chinach, jest dobre ${ }^{19}$. Daje też wyraz swojemu niezadowoleniu ze stanu literatury w ogóle - pisze, że pojęcie sukcesu zastąpiło ideę poświęcenia się sztuce, a młodzi twórcy niewiele wymagaja od siebie i to samo może dotyczyć też Chin. Ogromne wrażenie wywarła na mnie trafność diagnozy postawionej przez Różewicza. W rzeczy samej młode pokolenie w Chinach nazywane jest „małymi cesarzami” właśnie z powodu cieplarnianego

18 Ibidem, s. 265.

19 T. Różewicz, $W$ drodže [w:] Margines, ale..., s. 23. 
wychowania, któremu zostało poddane ${ }^{20}$. Poziom edukacji jest wysoki, ale opiera się na niewymagającym myślenia zapamiętywaniu danych, co niszczy kreatywność. Poeta nawiązuje również do problemu niszczenia środowiska w imię postępu i widać, że wizja przyszłości nie napawa go optymizmem.

Teksty Różewicza na temat wyprawy do Chin różni forma i język, ale łączy je poczucie niemożności opisania innego świata, braku odpowiedniego warsztatu, wystarczająco pojemnej wyobraźni. Porewolucyjne Państwo Środka jawi się w nich jako kraj postępu, w którym zwyciężyła rewolucja i propaganda, a naród niestrudzenie pracuje. Poeta, wtłoczony w rolę obserwatora, nie uczestnika ${ }^{21}$, zmaga się ze świadomością niedostępności prawdziwego oblicza Chin. Jednak obserwuje je wnikliwie, chłonąc każdy szczegół pozornie bliskiego - bo socjalistycznego, ale odległego kulturowo państwa. Zwraca uwagę na drobnostki odróżniające codzienność chińską od polskiej. Jest pełen szacunku do obcej kultury, choć czasami nie może się powstrzymać przed wyrokowaniem na jej temat. Co najciekawsze, na podstawie swoich doświadczeń w Polsce i Chinach całkiem trafnie ocenia stan cywilizacji i stawia prognozy dotyczące jej przyszłości. Postuluje powrót do natury i pracowitość w imię idei, a nie sukcesu mierzonego jedynie zyskiem i pieniędzmi.

\title{
SUMMARY
}

\author{
THE VISION OF PEOPLE'S REPUBLIC OF CHINA \\ IN THE WORKS OF TADEUSZ RÓŻEWICZ "SEN KWIATU, \\ SERCE SMOKA” [DREAM OF A FLOWER, HEART OF A DRAGON], \\ “DWA SKOKI I JUŻ PEKIN" [TWO LEAPS AND YET BEIJING], \\ "PRZELOT" [OVERFLIGHT] I "W DRODZE" [ON THE WAY]
}

Tadeusz Różewicz, a $20^{\text {th }}$-century Polish poet, travelled to China in 1958 . He wrote several prosaic texts about this travel and about his impression of China: "Sen kwiatu, serce smoka", "Dwa skoki i już Pekin", "Przelot" and "W drodze". He sees stewardesses as actresses in a kind of theatre, he thinks about the psychical condition of a humans on the board of a plane. He writes about European and Chinese part of Shanghai's identity, about Chinese characters' meaning, about Chinese people and their Four Pests Campaign. An important part is the description of a Four Pests Exhibition. The poet sees China as a different world and he knows that many facts have been hidden.

20 L.T. Chang, Z tote czasy w złotej klatce, „National Geographic” 2014, nr 5 (104), s. 16-31.

${ }^{21}$ K. Pospiszil, „Widzৃiatem uśmiechnięte twarze”, cåyli puste marginesy mony. Słów kilka o podróżach Tadeusza Różewricza po Chinach [w:] Różemicz: Dodawanie, red. E. Bartos, M. Cuber, Katowice 2012, dostępne online: http://www.ojkologia.us.edu.pl/artykuly/235/widzialem-usmiechniete-twarzeczyli-puste-marginesy-mowy-slow-kilka-o-podrozach-tadeusza-rozewicza-po-chinach/ (dostęp: 22.05.2017). 